\title{
Union wage effects
}

\section{What are the economic implications of union wage bargaining for workers, firms, and society?}

Keywords: trade unions, wages, bargaining, labor market, firm performance, productivity

\section{ELEVATOR PITCH}

Despite declining bargaining power, unions continue to generate a wage premium. Some feel collective bargaining has had its day. Politicians on both sides of the Atlantic have recently called for the removal of bargaining rights from workers in the name of wage and employment flexibility, yet unions often work in tandem with employers for mutual gain based on productivity growth. If this is where the premium originates, then firms and workers benefit. Without unions bargaining successfully to raise worker wages, income inequality would almost certainly be higher than it is.

\section{KEY FINDINGS}

\section{Pros}

๑ Trade unions maintain and improve workers' terms and conditions through bargaining with employers.

๑ Workers organized in trade unions benefit from higher wages-the so-called union wage premium.

๑ Union bargaining also results in a fringe benefits premium for covered workers.

๑ Trade unions reduce wage inequality.

๑ The counter-cyclical wage premium helps to maintain the real wages of covered workers.

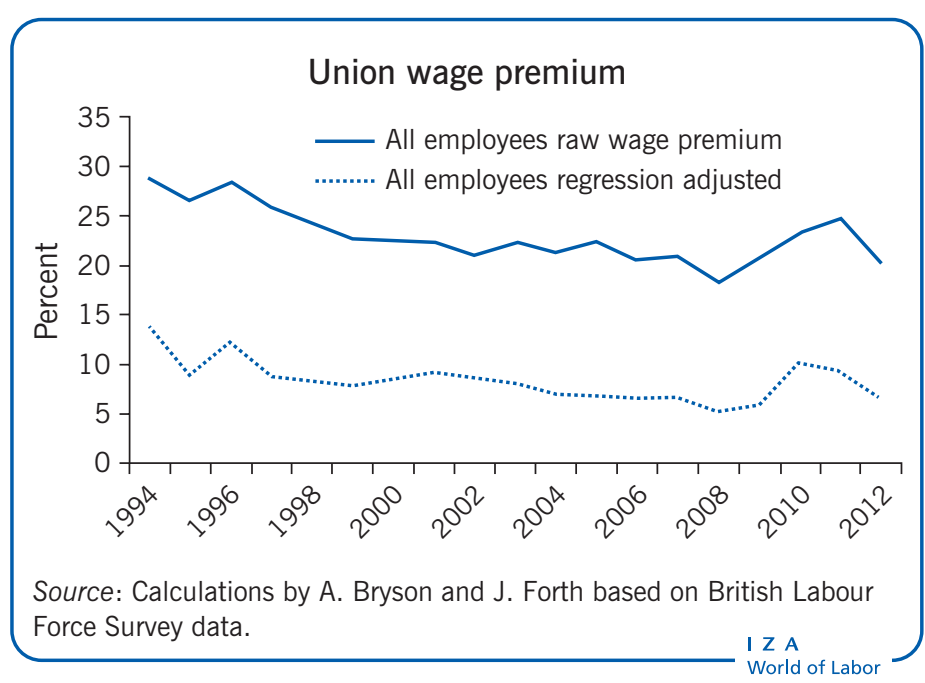

\section{Cons}

- Trade unions restrict employment flexibility.

- Trade unions prevent markets from clearing.

- By standardizing wages across regions, unions distort labor supply.

- Trade unions harm businesses if the return for additional wages is low.

- If the premium comes at the expense of normal profits, this can damage firms and employment growth.

\section{AUTHOR'S MAIN MESSAGE}

Unions continue to affect wage rises and reduce wage inequality despite reductions in their bargaining power. Society and firms can benefit when the union wage premium is the result of productivity growth. However, if raised wages come at the expense of normal profits, this can damage the prospects of firms and employment growth-to the longterm detriment of all. As union influence on wages has fallen, wage inequality has grown in many countries, perhaps to the detriment of most workers and employers alike. 


\section{MOTIVATION}

Union wage bargaining is perhaps the biggest departure from market wage-setting in modern economies. Unions' wage standardization policies that attach wages to jobs, not individuals, have important implications for wage dispersion. Unions' ability to limit the labor supply to firms so as to extract above-market wages can benefit workers but be detrimental to firms and employment. However, the implications of union wage-setting are complex. Factors include: union bargaining power; institutional arrangements for bargaining; unions' ability to negotiate over employment as well as wages; employer-union relations; and the profitability of the firms they organize. It is no surprise, therefore, that the implications of union wage bargaining for workers, firms, and society are heavily contested.

This article outlines the pros and cons of union wage bargaining, with empirical evidence on the size of effects across countries and over time. It points to limitations in our knowledge of the size of union wage effects and their origins. It concludes with implications for public policy.

\section{DISCUSSION OF PROS AND CONS}

\section{How do unions affect wages?}

Unions affect wage levels and dispersion in five ways-two direct and three indirect (see Mechanisms by which unions can affect wages). By threatening to limit the supply of labor, unions generate bargaining power, which they use to negotiate improved terms and conditions for covered employees, including wages. This power can also be used to resist downward pressure on wages, such as employer efforts to cut or freeze wages in an economic downturn. This makes union wages more rigid than non-union wages.

\section{Mechanisms by which unions can affect wages \\ Direct \\ - Bargaining on behalf of covered employees for increased wages. \\ - Bargaining on behalf of covered employees to maintain wages.}

\section{Indirect}

- Influence on other outcomes for covered employees, for example "voice" $\rightarrow$ higher tenure $\rightarrow$ firm-specific human capital investments (Freeman and Medoff, 1984).

- Threat of unionization raises wages in the non-union sector (Rosen, 1969).

- Job losses in union sector, resulting in excess labor supply to non-union sector.

Freeman, R. B., and J. L. Medoff. What Do Unions Do? New York: Basic Books, 1984.

Rosen, S. "Trade union power, threat effects and the extent of organization." Review of Economic Studies 36 (1969): 185-196. 
Unions can also affect covered employees' wages through processes other than wage bargaining. For example, in providing a "voice" for covered workers that allows employers to resolve problems and disputes, unions reduce quit rates, raise tenure, and thus provide employers and workers with an additional incentive to invest in firmspecific human capital, resulting in higher wages [1].

Union bargaining can affect wage-setting in the non-union sector in two ways that run in opposite directions:

- The first is the threat of unionization. This may lead non-union employers to raise wages in the hope that doing so will limit opportunities for unions to organize workers [2]. The threat effect therefore has the potential to close the gap between wages in the covered and uncovered sectors.

- On the other hand, if union-bargained wages result in job losses among unionized employees, this may result in an excess supply of labor to the non-union sector, which may depress wages there.

\section{Evidence for union wage effects}

\section{Is the union wage effect real?}

There is a long-standing debate as to whether unions have any effect at all on wages. Adam Smith in 1776 and Fleeming Jenkin in 1868 believed unions did raise wages, but Milton Friedman in 1950 thought they had little effect, because they could not affect the supply of labor. Instead, he said, they simply took the credit for what would have happened anyway. However, toward the end of the 20th century a consensus emerged that unions did affect wages [1], [3].

So how big is the effect, and where does it come from? Answers to the questions "How big?" and "Where from?" help determine whether union effects are welfare-enhancing or deleterious to firms and the economy. Getting clear answers to these questions is made difficult by tricky data and econometric problems in identifying a union causal effect on wages. It is hard to exclude unions from an economy and then experimentally insert them, or to separate direct bargaining effects on covered workers from the effects of unions on wage-setting in the economy at large. Nevertheless, some strides have been taken.

\section{Empirical evidence on the size of the union wage premium}

It is difficult to generalize about the size of union wage effects across countries because the nature of unions and the institutional settings in which they operate are vastly different. Until recently the literature was dominated by studies for English-speaking countries characterized by workplace or firm-level bargaining where unions organize workers with little or no statutory assistance from the state. Efforts to make crosscountry comparisons have relied on differentials between union members and nonmembers based on analyses of household surveys. In the empirical literature for the Anglo-American world what is usually estimated is the difference between the ceteris paribus earnings of union members and those of non-members. These estimates identify the wage gap between union members and non-members holding constant their individual and workplace characteristics. To illustrate, Figure 1 uses the International 
Figure 1. Union membership wage premium from around the world

\begin{tabular}{llc}
\hline Country & Years & Union \% increase \\
\hline Australia & 1994,1998, and 1999 & 12 \\
Austria & $1994,1995,1998$, and 1999 & 15 \\
Brazil & 1999 & 34 \\
Canada & $1997-1999$ & 8 \\
Chile & 1998,1999 & 16 \\
Cyprus & $1996-1998$ & 14 \\
Denmark & $1997-1998$ & 16 \\
France & $1996-1998$ & $3(\mathrm{~ns})$ \\
Germany & $1994-1999$ & $4(\mathrm{~ns})$ \\
Italy & 1994 and 1998 & 0 \\
Japan & $1994-1996,1998,1999$ & 26 \\
Netherlands & 1994 and 1995 & 0 \\
New Zealand & $1994-1999$ & 10 \\
Norway & $1994-1999$ & 7 \\
Portugal & $1998-1999$ & 18 \\
Spain & $1995,1997-1999$ & 7 \\
Sweden & $1994-1999$ & 0 \\
UK & $1993-2002$ & 10 \\
US & $1973-2002$ & 17 \\
\hline
\end{tabular}

Notes: Dependent variable log of earnings variously defined. Controls are age, age squared, years of schooling, private sector, hours, and union status. Sample restricted to employees. Germany includes East and West. Dependent variable defined as follows: Australia-Yearly income in Australian \$; Austria-Personal net income per month in shilling; Canada — In what range would your own personal income fall in Canadian \$; Chile-R's monthly net income in CLP; Cyprus - Monthly gross earnings before taxes in Cyprus pounds; Denmark—R's earnings per year before taxes in Dkr; France-R's monthly earnings in francs; Germany-R's net earnings per month after taxes and social insurance in DM Italy-R's net income per month in thousands of lire; Japan-How much did you earn yourself last year before taxes in thousands yen; Netherlands—R's income after taxes in Gld; New Zealand-Yearly income from all sources before tax in NZ\$; Norway_-Personal gross income before taxes and allowances in 1997 include retirement benefits, etc.; Portugal—R's monthly average net income in escudos; Southern Ireland—Weekly gross income before taxes and social insurance; Spain—R's monthly earnings in pts; Sweden—Approximate income per month before taxes in SEK; UK-Log hourly earnings; US--Log hourly earnings.

Source: ISSP, 1994-1999, apart from UK (British Social Attitudes Survey) and US (Current Population Survey). Based on Blanchflower, D., and A. Bryson. "Changes over time in union relative wage effects in the UK and the US revisited." In: Addison, J. T., and C. Schnabel (eds). International Handbook of Trade Unions. Cheltenham, UK: Edward Elgar, 2003; pp. 197-245 [4].

Social Survey Program (ISSP) data for 1994-1999 to estimate the union membership wage gap in 17 countries; additionally, data for the UK and US are provided for 1993 2002 (British Social Attitudes Survey) and 1973-2002 (Current Population Survey), respectively. There are five countries-France, Germany, Italy, the Netherlands, and Sweden-where the union wage premium is zero or not significantly different from zero (ns). This is "primarily due to the fact that unions are also able to control wage outcomes in the non-union sector" by extension of collectively bargained rates [4], p. 211. Although this points to diverse results across countries, it is problematic, because union bargaining coverage is not always strongly correlated with union membership. In that respect the US is unusual.

Evidence for the US and for the UK often points to a union membership wage premium of between $10 \%$ and $15 \%$, but effects vary across different parts of the wage distribution (see "Union affects on the wage distribution"). Union bargaining also results in a nonwage premium in the form of fringe benefits such as pensions and holiday pay. 
Where unions organize at workplace level it is possible to see the direct effect of unions on wages subsequent to a new organizing drive, especially when this results in a new employment contract with renegotiated wages, as is often the case in the US. In these settings, the size of union effects (on wages and other outcomes like share prices) reflects union bargaining strength, as indicated by the proportion of employees supporting the union. Not surprisingly, then, comparing wage changes where unions have only just won the support of employees in a workplace election with those where they have just lost reveals insignificant effects [5].

In most continental European countries, union bargaining can occur at various levels: workplace, firm, sector, region, or nationally. In some of these countries (such as France, Spain, Italy, and Denmark), it occurs at more than one level, such that the wage received by a worker will reflect bargaining at different levels and the degree to which this is coordinated. Where sectoral or national bargaining predominates, the outcomes from union wage bargaining are often extended to uncovered employees-such that the wage differential between union-covered and uncovered workers is reduced. Where there is a differential, it is due to local negotiated rates exceeding the "base" rate agreed more centrally (as has happened recently, for example, in Denmark). These union differentials can be sizable, but in the main they are not [6].

Nevertheless, as in the Anglo-American setting, the wage premium achieved through local bargaining is a function of union bargaining power (often indicated by the proportion of employees belonging to the union) and the financial gains that are available from the employer, as in the case of France.

Difficulties measuring the degree to which non-union employers are threatened by union organizing makes it hard to estimate the size of any union threat effect on wages in the non-union sector. A study using three methods (changes in right-to-work legislation, industry deregulation, and predicted likelihoods of unionization) in the US gives mixed results [7]. Similarly, although there do appear to be some disemployment effects associated with union bargaining (see "Consequences of union wage effects for employers"), it has proved difficult for analysts to establish the effects of any labor spillover on wage-setting in the non-union sector.

\section{Has the size of the union wage premium changed over time?}

There are at least three reasons why we might expect to see a decline in the union wage premium over time.

- $\quad$ First, rising market competition may have increased the price sensitivity of demand for goods and services, thus limiting unions' ability to demand wage hikes without contemplating potential job losses.

- Second, if increased market competition has reduced the number of employers with scope to pay higher wages, this increases the likelihood that unions will face greater employer resistance to their wage demands, since any premium is likely to cut into normal profits. 
- Third, unions face increased difficulties in monopolizing the supply of labor to firms. This is due to declining union density within unionized firms and the increased availability of non-union labor due to de-unionization in the home country. Globalization makes it easier for employers to import non-union labor directly (witness the recent disputes relating to posted workers in Europe) or to contract out to non-union labor in developing economies.

In fact, although the wage premium in the US and the UK has declined in recent years [8], [9], it remains sizable and statistically significant for most groups of employees.

There are perhaps four reasons for this:

- While the unionized sector has shrunk, unions continue to have a foothold in settings where their bargaining power has been particularly strong. For instance, in the UK the rate of union decline is slowest in industries where it is possible to extract higher pay. This is because unions work hard to retain a foothold in those sectors, and perhaps because employers in industries where higher pay can be extracted are less resistant to unionization than other employers.

- Union strongholds persist in occupations where unions have high bargaining power, such as health professionals.

- The weakening of unions' organizational capacity may have reduced the number of instances in which unionization is a credible threat to non-union employers-a factor that may keep non-union wages lower than might have been the case in the past.

- The degree to which competition has squeezed out union opportunities to extract higher wages from employers has, perhaps, been exaggerated. There remain a number of sectors where employers occupy monopoly or oligopolistic positions in markets for products or services, where the state dominates, or where regulation limits the amount of competition in the marketplace. These are all settings that unions can exploit to benefit their members.

The union wage premium is also counter-cyclical (i.e. out of phase with the underlying business cycle) [9], reflecting the time it takes to renegotiate long-term contracts with unions following unanticipated demand shocks, and, perhaps, unions' ability to block managerial attempts to downwardly adjust wages unilaterally, as can occur in the nonunion sector.

\section{Union effects on the wage distribution}

Union wage policies are often guided by the principle of "a fair day's pay for a fair day's work," such that wages are attached to jobs rather than individuals' attributes. This wage standardization policy, coupled with union concerns to tackle wage discrimination on grounds of race, gender, and disability, can compress wage differentials. It is difficult to disentangle these causal effects from effects arising from worker sorting across the union and non-union sectors.

Whether unions actually compress wage differentials depends on the position of unionized workers in the pay distribution, the union wage premium attached to different types of worker, and the degree of centralization and coordination in collective bargaining. 
Unions continue to compress wages in the US, Canada, and the UK, although there is some disagreement as to whether the effect is apparent for women [10].

Unions compress wages because the union wage premium is much larger for low-waged workers, and is modest or even negative further up the wage distribution. The decline in unionization has contributed substantially to the growth in wage dispersion. In the US it accounts for about one-quarter of the increase between 1979 and 2009, and in Germany de-unionization accounts for about one-third of the rise in wage inequality in the lower tail of the earnings distribution in the 1990s [11].

In those continental European countries where collective bargaining occurs locally and nationally or sectorally, local bargaining usually sets rates above the national level, but the effects of company-level agreements on pay dispersion differ across studies and countries [6].

\section{Consequences of union wage effects for employers}

Whether union wage effects have consequences for firm performance depends on a number of factors. Union wage effects can have positive benefits for employers where they induce increased worker productivity through worker sorting (if better workers are attracted by above-market wages), or increased worker effort due to efficiency wages,

\section{Factors affecting the impact of union wage effects on firm performance}

- Positive

- $\quad$ wages lead to increased labor productivity

- $\quad$ worker sorting

- $\quad$ worker effort (efficiency wages, fairer wages)

- $\quad$ increase capital intensity

- Neutral

- $\quad$ taken from surplus rents (no closure)

- high unionization among competitors, or extension of union pay rates

- $\quad$ wages are simply labor's share of bigger pie created by union

- Negative

- taken from normal rents

- shareholder response (Lee and Mas, 2012)

- wage compression reduces work incentives

- limit managerial discretion to pay for performance

- $\quad$ wage compression less attractive to high-ability workers

- reduce capital investment (insufficient funds; anticipate lower returns)

Lee, D. S., and A. Mas. "Long-run impacts of unions on firms: New evidence from financial markets, 1961-1999." The Quarterly Journal of Economics 127 (2012): 333-378. 
or reciprocation in return for fairer pay (if that is how workers perceive it). Firms may also benefit by becoming more capital-intensive in response to increases in the relative price of labor.

Alternatively, union wage effects may have little bearing on firm performance (neutral) where the premium arises because unions have successfully organized firms that can afford to pay more; where competitors also face union rates; or where the premium simply reflects the additional value created by the productivity-enhancing effects of a unionized labor force.

But the effects will have a negative impact on firms where the premium is extracted from firms that have no "excess" profits; where wage compression reduces work incentives or reduces the firm's ability to attract high-ability labor; where union seniority rules and the desire for wage standardization limit managerial discretion to pay for performance; and where capital investment falls owing to insufficient funds or where investors perceive that returns will be lower in the presence of a union.

Scholars in the 18th and 19th centuries came to the conclusion that unions were, in the main, a good thing, in that they raised wages without creating unemployment. More recently, there is no strong evidence that union wage bargaining results in workplace closure, a finding that lends credence to the idea that workers are aware of the potentially adverse consequences of making excessive wage claims. Unions respond to the median union member accordingly by moderating their wage claims. However, unionized workplaces in the UK, the US, Canada, and Australia appear to grow at a slower rate than their non-union counterparts. It is the low-skilled who receive the largest wage premium and who experience the largest disemployment effects. It is unclear whether this translates into a sizable employment spillover to the non-union sector.

There may have been some improvement in the financial performance of unionized workplaces in recent years compared with non-unionized workplaces [8]. Although this has been linked to unions seeking mutual gains with firms, the evidence of a substantial productivity differential between union and non-union plants is not strong. Furthermore, there is evidence that shareholders respond negatively to union organizing in the US, such that the share price of publicly traded firms falls by roughly $10 \%$ in the 15-18 months following a successful union election campaign. The effects are larger in firms where the majority voting union is substantial; that is, where employees reveal a strong preference for union-bargained wage gains.

\section{LIMITATIONS AND GAPS}

Despite a spate of studies focusing on continental Europe, studies from the Englishspeaking world still dominate what we know about union wage effects. Yet unions are an important part of developing economies. These studies grapple with very different economic and political settings, and portray unions as very different institutions from those we know through the existing literature. Differences in the nature of unionization, even in the developed world, mean that we need to take full account of differences in institutional settings. This means moving beyond simple estimates of differences between union members and non-members using household data, although this is often a good place to begin. 
Technical (estimation and data) questions continue to make it difficult to tease out causal effects of unions on wages and wage dispersion in union and non-union sectors. Furthermore, few attempts have been made to distinguish between types of union, despite their potential importance in understanding the wide range of union wage effects.

In the future, analysts should focus not simply on whether a union is present and how many workers it has, but also on the type of union it is, and the relations between it and management, which are, perhaps, the core of employment relations.

\section{SUMMARY AND POLICY ADVICE}

If unions do not cause the wage gap between union and non-union workers, no policy implications follow. Where unions challenge employers who pay below employees' true value, they may in fact perform a good by tackling discrimination or low pay and increasing workers' purchasing power. Although, in theory, it may be unsustainable to pay above-market wages, unions can benefit workers and firms alike if the wage premium reflects union-induced increases in productivity (see Factors affecting the impact of union wage effects on firm performance).

But is the propensity of unions to compress pay harmful? National public sector pay bargaining has received attention in the UK because it affects the quality of labor supplied to the whole public sector, depending on how nationally bargained pay rates there compare with the private (largely non-unionized) sector. These labor-supply distortions have been linked to adverse welfare outcomes-for example, poor hospital care. A more dispersed wage structure might create strong work incentives, although incentives may decline above a certain level of inequality. Also, perceptions of fairer pay can lead to greater worker effort if workers reciprocate for the "gift" of greater fairness.

Governments' perceptions of unions' effects on wages depend on whether they view current inequality levels as exacerbating or improving unemployment and poverty. Those keen to tackle perceived discrimination and wages below workers' worth may support union bargaining; those concerned about wage inflation and unemployment will prefer to let the market set wages. These political preferences have shifted, at least in countries like the UK, where public policy became less tolerant of union bargaining in the 1980s. In continental Europe, however, union bargaining remains key between social partners.

\section{Acknowledgments}

The author thanks an anonymous referee and the IZA World of Labor editors for many helpful suggestions on earlier drafts. Financial support from the Nuffield Foundation is gratefully acknowledged.

\section{Competing interests}

The IZA World of Labor project is committed to the IZA Guiding Principles of Research Integrity. The author declares to have observed these principles.

(c) Alex Bryson 


\section{REFERENCES}

\section{Further reading}

Bryson, A., and J. Forth. Trade Union Membership and Influence, 1999-2009. Centre for Economic Performance (CEP) Discussion Paper No. 1003, September 2010. Online at: http://cep.lse.ac.uk/ pubs/download/dp1003.pdf

Frandsen, B. R. Why Unions Still Matter: The Effects of Unionization on the Distribution of Employee Earnings. MIT Mimeo, 2012. Online at: http://www.ewi-ssl.pitt.edu/econ/files/seminars/120224_sem_ Brigham\%20Frandsen.pdf

Lewis, H. G. Unionism and Relative Wages in the United States: An Empirical Inquiry. Chicago, IL: University of Chicago Press, 1963.

\section{Key references}

[1] Freeman, R. B., and J. L. Medoff. What Do Unions Do? New York: Basic Books, 1984.

[2] Rosen, S. "Trade union power, threat effects and the extent of organization." Review of Economic Studies 36 (1969): 185-196.

[3] Lewis, H. G. Union Relative Wage Effects: A Survey. Chicago, IL: University of Chicago Press, 1986.

[4] Blanchflower, D., and A. Bryson. "Changes over time in union relative wage effects in the UK and the US revisited." In: Addison, J. T., and C. Schnabel (eds). International Handbook of Trade Unions. Cheltenham, UK: Edward Elgar, 2003; pp. 197-245.

[5] DiNardo, J., and D. S. Lee. "Economic impacts of new unionization on private sector employers: 1984-2001." The Quarterly Journal of Economics 119:4 (2004): 1383-1442.

[6] Bryson, A. "Union effects on wages." In: Marsden D., and F. Rycx (eds). Wage Structures, Employment Adjustments and Globalization: Evidence from Linked and Firm-Level Panel Data. Basingstoke: Palgrave Macmillan, 2010; pp. 174-184.

[7] Farber, H. S. "Non-union wage rates and the threat of unionization." Industrial and Labor Relations Review 58:3 (2005): 335-358.

[8] Blanchflower, D., and A. Bryson. "What effect do unions have on wages now and would 'what do unions do?' be surprised?” In: Bennett, J. T., and B. E. Kaufman (eds). What Do Unions Do?: A Twenty-Year Perspective. New Brunswick, NJ: Transaction Publishers, 2007; pp. 79-113.

[9] Blanchflower, D. G., and A. Bryson. "Trade union decline and the economics of the workplace." In: Brown, W., A. Bryson, J. Forth, and K. Whitfield (eds). The Evolution of the Modern Workplace. Cambridge: Cambridge University Press, 2009; pp. 48-73.

[10] Card, D., T. Lemieux, and W. C. Riddell. "Unions and wage inequality." Journal of Labor Research 25 (2004): 519-559.

[11] Dustmann, C., J. Ludsteck, and U. Schonberg. "Revisiting the German wage structure." The Quarterly Journal of Economics 124:2 (2009): 843-881.

The full reference list for this article is available from the IZA World of Labor website (http://wol.iza.org/articles/union-wage-effects). 